UDC 656.2

N.Y. Shramenko ${ }^{1,2}$, Dr. Sc. (Tech.), Prof., orcid.org/0000-0003-4101-433X,

V.O. Shramenko ${ }^{3}$, orcid.org/0000-0002-3551-6942
DOI: $10.29202 /$ nvngu/2019-3/15

1 - Kharkiv Petro Vasylenko National Technical University of Agriculture, Kharkiv, Ukraine

2 - Ukrainian State University of Railway Transport, Kharkiv, Ukraine, e-mail: nshramenko@gmail.com

3 - V. N. Karazin Kharkiv National University, Kharkiv, Ukraine, e-mail: shramenko.vlad@gmail.com

\title{
OPTIMIZATION OF TECHNOLOGICAL SPECIFICATIONS AND METHODOLOGY OF ESTIMATING THE EFFICIENCY OF THE BULK CARGOES DELIVERY PROCESS
}

Purpose. To increase the efficiency of the process of bulk cargo delivery by exit routes by optimizing the technological parameters of the supply chain.

Methodology. The optimization of the technological parameters of the supply chain for cargo delivery was carried out using mathematical modeling. To assess the effectiveness of the process of cargo delivery, an analytical method of research was applied.

Findings. As a result of the research, optimum values of the technological parameters of the production and transportation chain of ore cargo delivery by exit routes were obtained: the composition of the formed route is 38 cars, the loading point performance is $324.2 \mathrm{t} / \mathrm{h}$, the delivery interval is 1.75 days. Using the optimal technological parameters of the supply chain for the delivery of bulk cargoes by exit routes, the operational work of the railway transport is planned, ensuring compliance with the delivery interval for the purpose of implementing the requirement "just in time". The dependences of the specific costs of these parameters, which allow evaluating the nature of their changes in various given conditions, are constructed.

Originality. The components of the economic effect of the supply chain for the delivery of bulk cargoes (coal, ores, etc.) by means of exit routes have been formalized and a method for evaluating the economic effect for both subjects of the supply chain is proposed: the owner of cars and production.

Practical value. Recommendations on the formation of the technological process of functioning of the entire supply chain are given for given values of the duration of the supplier's and customer's production cycles, the duration of transportation, the intensity of the input of the delivered raw materials into production. To improve the efficiency of delivery of bulk goods, it is recommended to use the developed schedules of interaction between production, transport and consumption. At the same time, the intensity of raw materials receipt into production determines the optimal composition of the formed exit route and the delivery interval.

Keywords: exit routes, bulk cargo, iron ore, supply chain, technological parameters

Introduction. Consumers of transport services increase the requirements for the conditions of transport service, quantitative and temporal parameters, which necessitates the improvement of the system of organization of car traffic flows. Along with enhancing the technical equipment, the major challenge for transport is to improve the use of the rolling stock $[1,2]$.

Modern methods for increasing the efficiency of material flow management are undoubtedly of practical interest to the country's economy. Their application will enable the enterprises to effectively operate both on the domestic and foreign markets [3]. Most attention is paid to the application of logistic approach in selecting rational parameters of the distribution channels of cargo flows [4]. In terms of stable traffic flows between senders and recipients for the system of organizing railroad car flows, the most effective is the application of the logistics approach when delivering bulk cargo: iron ore, coal, oil products, etc.

Literature review. To reduce the expenses necessary for traffic flow processing, optimization of technological parameters of the process of functioning of production and transport complexes is required $[5,6]$. This allows

(C) Shramenko N. Y., Shramenko V. O., 2019 building a transport policy, taking into account the interests of cargo owners and, ultimately, increasing the traffic as well as improving the economic position of the railways [7].

In the conditions of the transport market, cargo delivery by the cargo owners is based on the criteria for assessing the quality of railway transport operations "just in time" and with minimal costs. Of great importance is the release of production stocks of raw materials when delivering goods "just in time" with optimal lots [8].

The researchers have substantiated the need to stimulate the senders to form sender routes in Ukraine [9]. Almost $80 \%$ of all ore, $76 \%$ of oil cargo, $61 \%$ of flux, $58 \%$ of coal, $43 \%$ of chemical and mineral fertilizers are transported on the routes.

The advantage of cargo transportation by routes consists in the fact that the cars on the given routes follow from the loading stations to the destination ones without being processed at passing technical stations, as a result of which the turnover time of the car is reduced, the delivery of goods is accelerated, the cost of transportation drops, and the volume of work at sorting and divisional stations decreases [10].

The main disadvantage of theoretical and practical developments in the field of operating the production 
and transport systems is insufficient interaction between production workshops and the transport system [11].

To minimize the costs of resources and to fulfill the principle of delivering goods "just in time", it is necessary to organize a technological process that involves the interaction of production, transport and consumption $[12,13]$.

Technological harmonization of the work of the manufacturer, transport sector and production consumer results in obtaining a synergistic effect [14].

The technical and technological structure of the PTC depends on many factors: the form of material and technical supply, the range of manufactured products, the type of trunk transport, the methods for organizing transportation (technological routes, wagon lots), the features of production technology, etc. [15].

It has been established that at present forms and methods of interaction between production and transport appear to be ineffective, and the management of the material flow process is based on unilateral and unjustified expenditures of transport resources. To solve the problem in question, a new approach based on the development of optimization models for productiontransport system subsystems operation [16] is needed.

The generalizing parameter of transport-logistic processes is efficiency [17]. There are many approaches and techniques to assessing the effectiveness of production and transport processes. It remains difficult to make an economic assessment of various activities, selected services or transport operations [18].

The research shows that analysis of technical and operational parameters of transport and transportation processes helps to identify the reserves for increasing the efficiency of transport performance [19].

Purpose. The purpose of the study is to increase the efficiency of the process of bulk cargo delivery by exit routes by optimizing the technological parameters of the supply chain.

\section{Research objectives are:}

- to carry out modeling of the production and transportation chain operation for bulk cargoes delivery (by the example of iron ore raw materials) by technological routes and analyze the results obtained;

- to develop practical recommendations on the formation of the technological process of joint work of the subjects of the entire production and transport chain operation (PTC);

- to develop a methodology for assessing the economic effect of the bulk cargo delivery process (coal, ores, etc.) by exit routes.

Methods. To determine the rational technological parameters of the production and transport chain for bulk cargo delivery, mathematical modeling was applied. Estimation of the efficiency of bulk cargo delivery by exit routes is based on the analytical research method.

Results. In most cases, the cars of the network fleet are fed to the quarries (or mines) by routes and returned back in the same manner. Empty trains arriving for loading are usually taken to the assembly (control) station to be further divided into separate groups of cars, which are then fed to the loading areas. As a result of the uneven approach of empty cars, both on separate days, and during these days, conflicts arise.

In these conditions, it is necessary to create a fixed rate of gondola cars stock as their technical and commercial failure is possible.

As a result of earlier studies on example of iron ore raw materials delivery, a target function [20] was formed, which is the specific costs associated with the operation of the entire PTC: the costs of the supplier to execute the order; the costs of finished products storage at the shipper's distribution center; costs associated with transportation by the main transport; the cost of storing goods at the consignees' location.

Unmanaged parameters are as follows: duration of the metallurgical enterprise production cycle $Q_{n}$, due to the technical equipment of the loading and unloading points, the shipping fee $T_{a r}$, and the car hire charge $S_{\text {ser }}$.

The optimized parameters are the following: the exit route train $m$, the performance of the loading areas $q_{\text {load }}$, the delivery interval $n$, the specific costs per one car $R_{\text {min }}$.

For optimized parameters, the range of their changes was analyzed.

The productivity of ore mines constitutes up to $200 \mathrm{t} /$ per day for small ones; for medium ones to $700 \mathrm{t} /$ per day and large up to $5000 \mathrm{t} /$ per day and more. On this basis, a range of changes in the performance of the loading point $q_{\text {load }} \in[80 ; 600]$ was set, given the current loading. The maximum number of cars included into the train is due to the length of the receiving and dispatch tracks as well as the train mass limitations depending on the type of locomotive, the profile of the road, the type of the rolling stock, the rolling stock loading capacity, the speed of movement under the estimated lift, and, as a rule, it does not exceed 60 cars, therefore $m \in[0 ; 60]$ was assumed.

The simulation was carried out for the set values of the mathematical model uncontrolled parameters.

On the basis of the simulation results obtained, graphs of the dependencies of the total costs on the parameters of the traffic channels freight flows (Figs. 1, 2), according to which the tendency of the investigated function behavior is analyzed, are constructed.

The simulation results show that, with the increase in the performance of the loading point $q_{\text {load }}$ up to the value of $324.2 \mathrm{t} / \mathrm{h}$, the cost of $R$ per car is reduced to reach $1280.7 \mathrm{cu} / \mathrm{wt}$. The composition of the route being formed in this case is optimal and equals 38 cars, and the delivery interval is 1.75 days. Further, with the increase in the parameter $q_{\text {load }}$, an increase in the total costs of $R$. is observed. This is due to the fact that with the increase in the performance of the $q_{\text {load }}$ loading point, an additional cost for the maintenance of loading and unloading mechanisms arises. These costs exceed the savings achieved by reducing the downtime of cars under loading.

Fig. 1 shows the dependence of the specific costs per car on the number of cars in the technological route, which makes it possible to determine the technological route optimal composition at different loading point performance.

In the case of restrictions on the technological route composition $m$, the optimum performance of the $q_{\text {load }}$ 


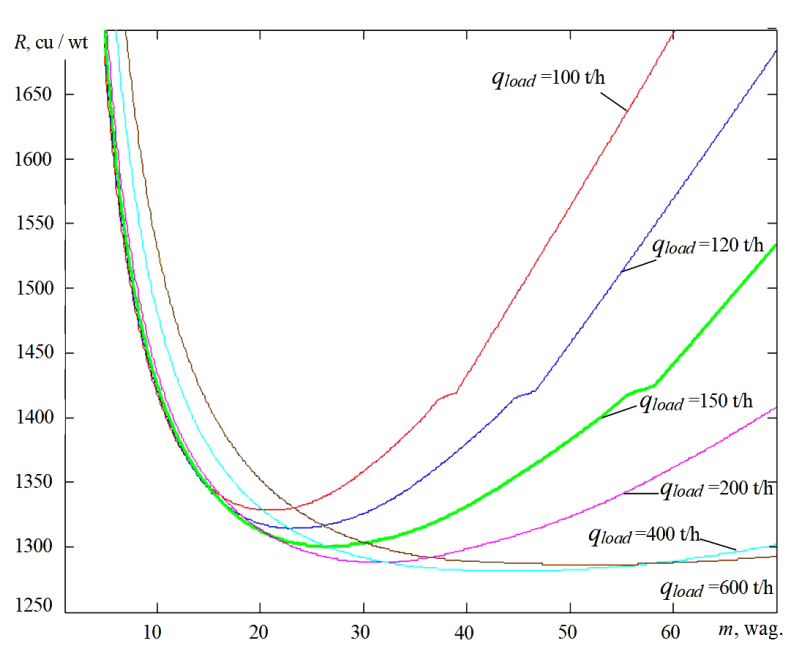

Fig. 1. Dependence of unit costs per car on the composition of the technological route

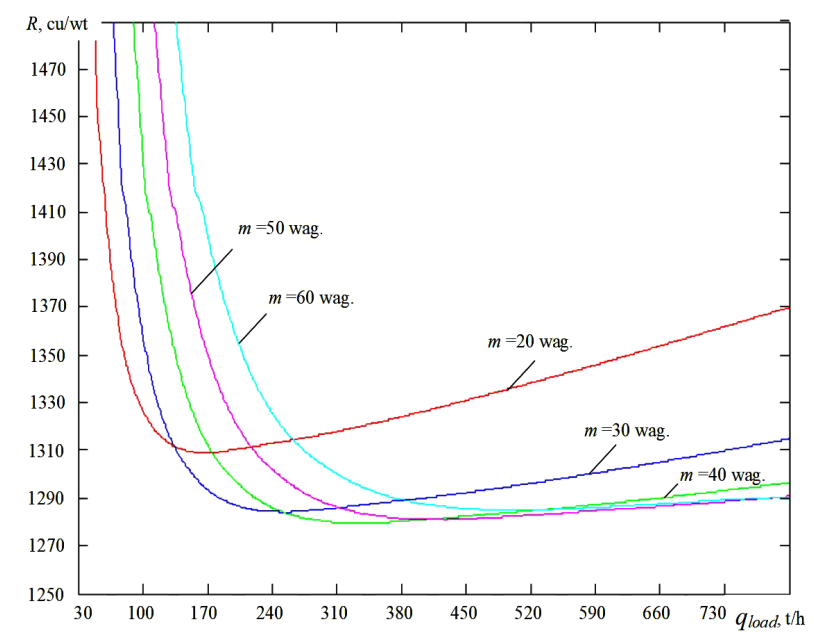

Fig. 2. Dependence of specific costs per car on the loading point performance

loading point can be established with the dependencies obtained (Fig. 2) for the contractual value of the transport dispatch (composition of the technological route). So, at $m=22$ wag. : $=187 \mathrm{t} / \mathrm{h}, R=1303.6 \mathrm{cu} / \mathrm{wt}$.

Thus, as a result of modeling the operation of the production and transport chain for the delivery of ore cargoes by exit routes, the size of the cargo batch $m$ in various specified conditions is determined.

Having obtained the optimal values of unit costs for each group of indicators $\left(q_{\text {load }}, m, n\right)$, it is possible to consider the measures requiring improvements in technical equipment and rationalization of technologies that facilitate their achievement.

In general, as a result of modeling the process of functioning of the production transport chain of ore cargoes supply by exit routes, the rational values of technological parameters were obtained: the size of the consignment $m$, the performance of the loading point $q_{\text {load }}$, and the delivery interval $n$.

The efficiency of the production and transport chain operation for delivery of bulk cargoes by exit routes is specified by the following indicators: the intensity of delivery of goods, the implementation of the agreed delivery time, the duration of the order service cycle, the size of the consignment, the level of capacity utilization, preserving the quality of the cargo upon delivery.

As a result of the rational technological parameters obtained, the potential effect for the owner of both the cargo and cars is estimated.

The formalization of separate components of the economic effect is proposed.

Reduction of the unit costs per car due to the formation of the exit route by the railroad train $m_{\text {opt }}$

$$
E_{1}=R_{f}-R_{\min } \text {. }
$$

In the delivery of goods "just in time" there is a problem of reducing inventory levels. Researchers estimated that the moratorium of capital in stocks makes up more than one third; the maintenance of reserves requires $20-40 \%$ of all consumer costs, including the cost of transport and warehousing operations.

The effect of reducing the loss of cargo due to minimizing the transportation and storage time is

$$
E_{2}=\xi \cdot q_{a v}^{s t} \cdot C_{\text {load }} \cdot \Delta t,
$$

where $\xi$ is the rate of natural loss of the cargo carried,\%; $q_{a v}^{s t}$ is the average static load of the car, t; $C_{\text {load }}$ is the average cargo price, $\mathrm{cu} / \mathrm{t} ; \Delta t$ is an increase in the delivery time, day.

$$
\Delta t=\frac{q_{a v}^{s t}}{24}\left(\frac{m}{q_{\text {load }}}-\frac{m_{\text {opt }}}{q_{\text {load }}^{\text {opt }}}\right),
$$

where $m, m_{\text {opt }}$ is the actual and optimal composition of the exit route, respectively, weight; $q_{\text {load }}$ is the actual and optimal performance of loading fronts, respectively, $\mathrm{t} / \mathrm{h}$.

The economic effect as a result of reducing the "dead capital" on wheels and in stock and reducing the working capital stock

$$
E_{3}=\frac{C_{\text {load }} q_{a v}^{s t}(1-\xi) \Delta t i}{360},
$$

where $i$ is the interest rate on deposits, shares; 360 relates to the number of days in a year, which is taken while performing calculations.

Since the implementation of the delivery principle "just in time" is accompanied by an increase in the speed of material flow movement, the economic effect of accelerating the turnover of cars contributes to reducing the service time in all phases of delivery. The effect of accelerating the car turnover will be expressed (in the conditions of deficit, which is typical for the current situation of the car fleet) in reducing the rolling stock operating fleet as well as the costs for maintenance of the latter.

$$
E_{4}=\frac{\Delta t C_{w a g} A_{a r}}{365},
$$

where $C_{w a g}$ is the car selling price, $\mathrm{UAH} ; A_{a r}$ is allowance for car depreciation and repair, $\%$

Overall economic effect for both PTC subjects is:

- that of the owner of cars 


$$
E_{\text {rail. }}=E_{4} m 365 / n ;
$$

- that of production

$$
E_{p r}=365\left[\left(E_{1}+E_{2}+E_{3}\right) m\right] / n .
$$

To realize the basic requirement when delivering products to the consignee (delivery of goods "just in time") and achieve a high efficiency of the system's operation, a technological process of joint work of subjects of the entire production and transport system based on the integration of production, transport and consumption should be developed and implemented.

The production cycle of the vendor is interchangeable, with the number of shifts depending on a number of uncontrolled parameters: the density of transport and material flows, the performance of loading and unloading machines and distribution systems, etc. The shipment of raw materials is carried out in a deterministic mode, which is primarily due to the technology of minerals extraction and the dressing complex operation, as well as the specifics of cargo itself. In turn, the production cycle of the enterprise-user is oriented to the roundthe-clock operation mode. Moreover, the intensity of raw materials supply for production should correspond to the optimal ore supply $m_{\text {opt }}$.

The process of raw materials supply (coal, ores, etc.) to the consignee involves several stages (Fig. 3).

Finished products are stored at the manufacturer's location at the time of shipment, being the first stage. At the second stage of cargo transportation, operations on vehicles loading are carried out. The third and main stage is the transportation process itself. Then, the product is unloaded and delivered to the consumer's warehouse (the fourth stage), where it is also stored in the form of stock up to the time of consumption (the fifth stage).

Using the optimal technological parameters of the production and transportation chain for the delivery of bulk cargoes by exit routes, the operational work of the railway transport is planned, ensuring compliance with the delivery interval for the purpose of implementing the "just in in time" requirement.

For the further development of high-tech production and transport systems, significant investments are

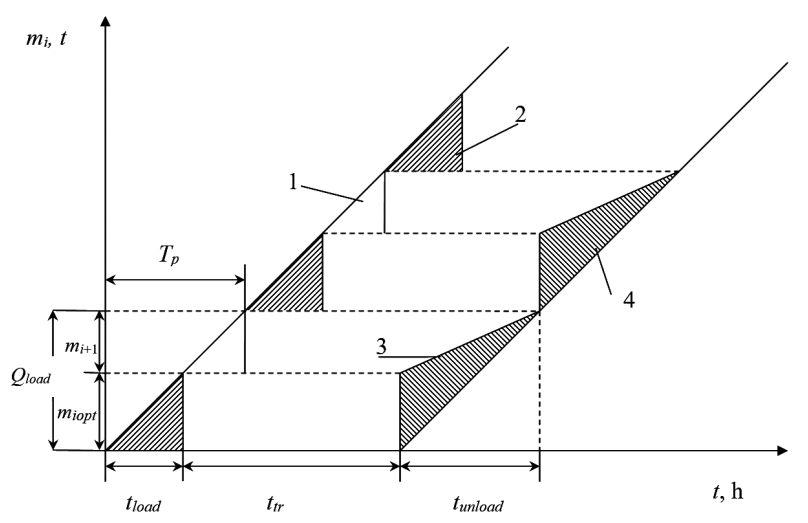

Fig. 3. Schedule of interaction of production, transport and consumption:

1 - production and accumulation; 2 - loading; 3 - admission; 4-consumption needed. Efficient use of investment will provide an integrated approach that will ensure the optimal sequence of development of elements of the production and transport system.

Conclusions. The conducted studies made it possible to draw the following conclusions:

- as a result of modeling, the optimum values of the technological parameters of the production and transportation chain of ore cargoes delivery by exit routes were obtained: the composition of the formed route is 38 cars, the loading point performance is $324.2 \mathrm{t} / \mathrm{h}$, the delivery interval is 1.75 days. The dependences that make it possible to estimate the character of the indicated parameters change under the existing conditions are constructed;

- the components of the economic effect of the production and transport chain for the delivery of bulk cargoes (coal, ores, etc.) by means of exit routes have been formalized and a method for evaluating the economic effect for both PTC subjects is proposed: those of the owner of cars and of production;

- practical recommendations are suggested for creating a unified technological process for the entire PTC functioning with time regulation of the production cycle of both the supplying and the consumer enterprise, the intensity of raw materials supply for production, and the duration of transportation;

- schedules of interaction of production, transport segment and consumption are developed, the application of which will enable to achieve an increase in the efficiency of bulk cargo delivery. At the same time, the intensity of raw materials supply for production should correspond to the optimal batch of dispatch.

The advanced research direction has been determined to be the analysis of conflict situations arising as a result of the uneven car supply for loading.

\section{References.}

1. Fedorovich, V. O., \& Kubrak, N. A. (2014). An analysis of economic conditions and factors contributing to improving the efficiency of freight transport in the perspective of organizing technological outsourcing. Bulletin of Tomsk State University. Economy, 3(27), 66-78.

2. Moroz, M. M. (2015). Defining the term and the volume of investments on reduction to necessary structure of rolling stock of passenger public transport (Kremenchuk city case study). Actual Problems of Economics, 166(4), 235-243.

3. Zharkova, A. A., \& Druzhinina, M. G. (2017). Model of the organization of transportation of bulk cargo in the industrial region. High technologies of development and use of mineral resources, 3, 265-268.

4. Muzylyov, D. A., Kravcov, A. G., Karnayh, N. V., Berezhnaja, N. G., \& Kutiya, O.V. (2016). Development of a methodology for choosing conditions of interaction between harvesting and transport complexes. Eastern European Journal of Enterprise Technologies, 2(3), 11-21. DOI: $10.15587 / 1729-4061.2016 .65670$.

5. Shramenko, N. Y. (2015). Effect of process-dependent parameters of the handling-and-storage facility operation on the cargo handling cost. Eastern European 
Journal of Enterprise Technologies, 5/3(77), 43-47. DOI: $10.15587 / 1729-4061.2015 .51396$.

6. Shatrova, K.I. (2016). The experience of foreign countries in the formation of transport and logistics systems. Public administration and customs administration, 1(14), 90-100.

7. Burmistrova, O. N., Sushkov, S. I., \& Pilnik, Yu. N. (2015). Optimization of parameters of transport processes at the enterprises of the timber industry complex. Fundamental research, 11(2), 237-241.

8. Kuzubov, A.A. (2017). System features inventory management in the logistics system business. Azimuth of Scientific Research: Economics and Administration, 6(4(21)), 137-140.

9. Verlan, A. I. (2013). Perfection of methods for stimulating sender routing on railway transport. Science and Transport Progress: Bulletin of Dnipropetrovsk National University of Railway Transport after academician V. Lazaryan, 49, 75-85.

10. Verlan, A.I., Pinchuk, E.P., \& Zhuravel, I. L. (2014). Improving the methods of technical and economic assessment of the efficiency of cargo transportation by sender routes. Coll. of sci. works of DSURT after academician V. Lazaryan, 7, 10-14.

11. Nefyodova, Y. I., \& Bulgakova, J. V. (2013). Modeling of management processes in integrated production and transportation system. Bulletin of the Azov State Technical University. Series: Technical Sciences, 27, 205213.

12. Shamis, V.A., \& Mochalin, M. S. (2016). Some aspects of functioning of transport and logistic processes. Modern technics and technologies, 11(1). Retrieved from http://technology.snauka.ru/2016/11/10897.

13. Shramenko, N.Y. (2017). Evaluation of the effectiveness of piggyback traffic in the context of creating transport and logistics clusters. Naukovyi Visnyk Natsionalnoho Hirnychoho Universytetu, 6(162), 151-155.

14. Shramenko, N. Y. (2016). Methodology for evaluation of synergy effect in terminal cargo delivery system. Actual Problems of Economics, 8(182), 439-444.

15. Taran, I., Turpak, S., Fomin, O., \& Tretyak, O. (2018). Logistik technology to deliver raw material for metallurgical production. Naukovyi Visnyk Natsionalnoho Hirnychoho Universytetu, 1(163), 162-169. DOI: $10.29202 /$ nvngu/2018-1/3.

16. Parunakajn, V. E., \& Maslak, G. V. (2017). Increase of production and transport co-operation efficiency in the material traffic at metallurgical enterprises. Bulletin of the Azov State Technical University. Series: Technical Sciences, 35, 237-244.

17. Baramidze, M., Lekveishvili, G., \& Gogiashvili, P. (2016). Methods of evaluating the performance of transportation companies using the principle of logistics. YEAR XXIV, 2, 56-58.

18. Shamis, V.A., \& Mochalin, M.S. (2016). Analysis of indicators of efficiency of transport and logistic processes. Modern technics and technologies, 12(1). Retrieved from http://technology.snauka.ru/2016/12/10903.

19. Belozerova, I. G. (2013). The economic effect arising from the improvement of the system of planning the transportation of goods. Engineering Bulletin of the Don,
26(3(26)). Retrieved from https://cyberleninka.ru/ article/n/ekonomicheskiy-effekt-voznikayuschiy-prisovershenstvovanii-sistemy-planirovaniya-perevozokgruzov.

20. Shramenko, N.Y., \& Shramenko, V.O. (2018). Mathematical model of the logistics chain for the delivery of bulk cargo by rail transport. Naukovyi Visnyk Natsionalnoho Hirnychoho Universytetu, 5(167), 136-141. DOI: $10.29202 /$ nvngu/2018-5/15.

\section{Оптимізація технологічних параметрів і методологія оцінки ефективності процесу доставки масових вантажів}

\section{Н. Ю. Шраменко ${ }^{1,2}$, В.О. Шраменко ${ }^{3}$}

1 - Харківський національний технічний університет сільського господарства імені Петра Василенка, м. Харків, Україна

2 - Український державний університет залізничного транспорту, м. Харків, Україна, e-mail: nshramenko@ gmail.com

3 - Харківський національний університет імені В. Н. Каразіна, м. Харків, Україна, e-mail: shramenko.vlad@gmail. com

Мета. Підвищення ефективності процесу доставки масових вантажів відправницькими маршрутами за рахунок оптимізації технологічних параметрів логістичного ланцюга.

Методика. Оптимізація технологічних параметрів логістичного ланцюга доставки вантажів виконана за допомогою математичного моделювання. Для оцінки ефективності процесу доставки вантажів застосований аналітичний метод дослідження.

Результати. У результаті дослідження отримані оптимальні значення технологічних параметрів виробничо-транспортного ланцюга доставки рудних вантажів відправницькими маршрутами: склад маршруту, що формується - 38 ваг., продуктивність пункту навантаження - 324,2 т./год, інтервал постачання - 1,75 діб. За допомогою отриманих оптимальних технологічних параметрів логістичного ланцюга доставки масових вантажів відправницькими маршрутами планується експлуатаційна робота залізничного транспорту, що забезпечує дотримання інтервалу постачання з метою реалізації вимоги „точно у строк“. Отримані залежності питомих витрат від зазначених параметрів, що дозволяють оцінити характер їх зміни в різних умовах, що задаються.

Наукова новизна. Формалізовані складові економічного ефекту логістичного ланцюга доставки масових вантажів (вугілля, руди й т.п.) відправницькими маршрутами і запропонована методологія оцінки економічного ефекту для обох суб'єктів логістичного ланцюга: власника вагонів і виробництва.

Практична значимість. Запропоновані рекомендації щодо формування технологічного процесу функціонування всього логістичного ланцюга при заданих значеннях тривалості виробничих циклів 
постачальника та споживача, тривалості транспортування, інтенсивності надходження доставленої сировини у виробництво. Для підвищення ефективності доставки масових вантажів рекомендується застосовувати розроблені графіки взаємодії виробництва, транспорту та споживання. При цьому інтенсивність надходження сировини у виробництво обумовлює оптимальний склад відправницького маршруту та інтервал постачання.

Ключові слова: відправницькі маршрути, масові вантажі, залізна руда, логістичний ланцюг, технологічні параметри

\section{Оптимизация технологических параметров и методология оценки эффективности процесса доставки массовых грузов}

\section{Н. Ю. Шраменко ${ }^{1,2}$, В. А. Шраменко 3}

1 - Харьковский национальный технический университет сельского хозяйства имени Петра Василенко, г. Харьков, Украина

2 - Украинский государственный университет железнодорожного транспорта, г. Харьков, Украина, e-mail: nshramenko@gmail.com

3 - Харьковский национальный университет имени В. Н. Каразина, г. Харьков, Украина, е-mail: shramenko. vlad@gmail.com

Цель. Повышение эффективности процесса доставки массовых грузов отправительскими маршрутами за счет оптимизации технологических параметров логистической цепи.

Методика. Оптимизация технологических параметров логистической цепи доставки грузов выполнена с помощью математического моделирования. Для оценки эффективности процесса доставки грузов применен аналитический метод исследования.

Результаты. В результате исследования получены оптимальные значения технологических параметров производственно-транспортной цепи до- ставки рудных грузов отправительскими маршрутами: состав формируемого маршрута - 38 ваг., производительность пункта погрузки - 324,2 т./ч, интервал поставки - 1,75 сут. С помощью полученных оптимальных технологических параметров логистической цепи доставки массовых грузов отправительскими маршрутами планируется эксплуатационная работа железнодорожного транспорта, обеспечивающая соблюдение интервала поставки с целью реализации требования „точно в срок“. Получены зависимости удельных затрат от указанных параметров, позволяющие оценить характер их изменения в различных задаваемых условиях.

Научная новизна. Формализованы составляющие экономического эффекта логистической цепи доставки массовых грузов (угля, руды и т. п.) отправительскими маршрутами и предложена методология оценки экономического эффекта для обоих субъектов логистической цепи: собственника вагонов и производства.

Практическая значимость. Предложены рекомендации по формированию технологического процесса функционирования всей логистической цепи при заданных значениях продолжительности производственных циклов поставщика и потребителя, продолжительности транспортировки, интенсивности поступления доставленного сырья в производство. Для повышения эффективности доставки массовых грузов рекомендуется применять разработанные графики взаимодействия производства, транспорта и потребления. При этом интенсивность поступления сырья в производство обуславливает оптимальный состав отправительского маршрута и интервал поставки.

Ключевые слова: отправительские маршруты, массовые грузы, жкелезная руда, логистическая цепь, технологические параметры

Рекомендовано до публікації докт. техн. наук А. В.Прохорченком. Дата надходжсення рукопису 10.08.17. 